International Journal of Engineering \& Technology, $7[2.29][2018] 692-695$
International Journal of Engineering \& Technology
SPC
Website: www.sciencepubco.com/index.php/IJET
Research paper

\title{
The Relationship Established Between Indonesian Political and Bureaucratic Official
}

\author{
Azhari* \\ FISIP, USN Kolaka \\ *Corresponding Author E-Mail: Azhari@Usn.Ac.Id
}

\begin{abstract}
The overlapping responsibility between the political and bureaucratic officials seems not to be avoidable due to the weaknesses of personnel management system. This condition, of course, leads to a clutter in some aspects such as recruitments, promotions, and political structures. This research aims to investigate the relationship between the political and bureaucratic officials in terms of authority which is applied by the officials and the factors that caused the overlapping authority. To do so, a descriptive qualitative analysis was applied in this research since the researcher would like to report the result in what looked like. The saturated data was collected by conducting an in-depth interview and documentations and it was analyzed qualitatively. The findings of the current research showed two models of relationship namely executive assendency and model of Party State Bureaucracy begun from the NewEra to Post New-era. Neither New-Era nor Post New-era are appropriate to be applied in the Southeast Sulawesi. Therefore this research suggested a more appropriate model of bureaucratic management, especially regional governance in Southeast Sulawesi namely the External Model of Executive Assendency or Personal Excecutive Assendency.
\end{abstract}

Keywords: Political official; Bureaucratic officials; Buracracy; and External Model of Executive Assendency or Personal Excecutive Assendency

\section{Introduction}

The writing related to the politicization of bureaucracy in Indonesia includes the writings of [1] in the book entitled: "Birokrasi dan Politik di Indonesia" [Bureaucracy and Politics in Indonesia]. This writing reveals the existence of bureaucracy in the political arena of political elites. Beside reviewing the bureaucratic position by elaborating the bureaucratic political theories. The book elaborates the bureaucratic condition, especially in Indonesia. However, the writing has not been specified to describe how the behavioral pattern of the relationship occurs between political officials and bureaucratic officials in the practice of governance.

Moreover, a study on the relationship between the political elites and the bureaucracy was also conducted by [2] entitled: "Terbentuknya sebuah Elit Birokrasi" [The Formation of a Bureaucracy Elites] was built from a historical perspective that described how the bureaucratic elites were able to be formed. In Indonesia, this book elevated the running of political and bureaucratic relationship from colonialism to the beginning of the new order era.

Furthermore, in his book entitled: "Politik, Birokrasi, dan Pembangunan" [Politics of Bureaucracy and Development], [3] examined the political perspective of bureaucracy in terms of political economy. This study describs that the politicization of bureaucracy in the third world was related to the willingness of foreign investors.

In another book entitled: "Kajian Awal Birokrasi Pemerintahan dan Politik Orde Baru" [The Preliminary Review of Governance Bureaucracy and Politics of New Order], [4] described the existence of bureaucracy in the context of national development in the 1980s. This study was not able to reveal how the bureaucracy was used for the interests of the new order political elites.

Other studies on the politicization of bureaucracy in Indonesia were conducted. [5] wrote a research entitled: "Politik Dalam Birokrasi; Studi Tentang Politisasi Birokrasi dan Politik Birokrasi" [Politics in Bureaucracy: Studies on Politicizationof Bureaucracyand Politics of Bureaucracy]. The study took the location setting in Surabaya City, which described how local bureaucratic officials should be related to other local political officials, especially those in the local parliament [DPRD]. Another study entitled: "Rekrutmen untuk mengisi jabatan struktural dan beberapa faktor yang mempengaruhinya" [Recruitment for Filling the Structural Positions and Some Factors Affecting It] by [6] was done to examine the existence of factors affecting the working process of the bureaucracy. This research suggested that there are two main factors affecting the recruitment of structural positions. One is the internal factors in the form of competence, experience, rank, education and health. The other is the external factors such as the recruitment system, referring to the regulatory system governing the appointment.

A study on the intervention of politicians towards bureaucracy and the influence of politicians towards the policy of bureaucrats' promotion and deprivation was conducted in Surabaya municipality and Situbondo District of East Java Province in the era of regional autonomy. The findings showed a strong influences of external politics in relation to the career of the bureaucratic officials, Secretary of region in Surabaya, and Situbondo dismissed by the Regent / Mayor due to the disharmonization of relationship among the bureaucratic officials, the politicians in DPRD, and the party that supported the local political officials.

There was also another study conducted by [7] that examined the use of bureaucratic discretion space in the context of local politics 
and accountability system in the era of regional autonomy, by taking the location in Surabaya municipality, Situbondo, and Bima districts. Through the study, it was found that the bureaucratic discretion in the autonomy era tended to be more open and the intervention role of local politicians was also more prominent Comparing with the previous research, the present study also did not specifically address the intervention of political officials in the career of bureaucratic positions. In addition, it did not examine the existence of bureaucrats working in the general governance and the local governance sector. Instead, the focus of this research is on the political officials' intervention on a bureaucratic career in the recruitment and promotion of bureaucratic positions.

The overall aforementioned studies did not closely examined the relationship between political and bureaucratic officials and did not provide a specific analysis of the factors that led to the formation of an Indonesian personnel system, especially when it was linked to the political culture and legal framework underlying the implementation of the Indonesian personnel management system.

However, there were few studies that are in line with the current research. [8], conducted a study entitled: "The relationship between the bureaucratic and political leadership". He found that there was a close relationship between political leaders and bureaucratic leaders because of the relationship of cultural equality. Unfortunately, this study was not able to prove the existence of any relationship among equality of ethnic, religious, and cultura education in the promotion of bureaucratic officials due to time constraints and research respondents.

Another study but in Indian context, it is found that there was a gap between what political leaders thought and what their bureaucracy was thinking about. The thought of its political leaders was about their own performance whilst the bureaucracy was about the views of its bureaucratic staff. Another finding was that both political and bureaucratic leaders wanted their votes accommodated in policy formulation. The study was in line with the findings of in Korea, who found that the close relationship between politicians and bureaucracy became a necessity of a state administration, in the view of [9] who found that bureaucracy expected its ministers understand his work and being able to answer the legislative questions in parliament.
It is clear that the existing writings have not revealed what caused the politicization of the bureaucratic position. In addition, the writings "have not been able to express how the relationship established between political officials and bureaucratic officials, as well as what factors were driving the relationship". Thus, the authenticity of this research lies on its efforts to reveal how the bureaucratic and political relationship happening in the Province of Southeast Sulawesi, Indonesia.

\section{Methodology}

With regard tothe objectives of the current research, the writer adopted qualitative approach. This approach is used because this study is seeking to investigate the relationship between political and bureaucratic official, which previously has been already investigated the concept of political intervention toward bureaucracy which is analyzed based on the concept of bureaucratic management.

The type of data which have been gathered is a primary data, which were collected from respondents who were involved in the local governance process in Southeast Sulawesi.

The primary data obtained from the informants by conducting an in-depth interview while the secondary data was taken from legislation, expert judgements, previous research findings, related studies, printed mass media, documentation, and etc.. Both types of data were processed and analyzed. Later on, the analyzed data became the main reference to find out other supporting data which were considered necessary to support and complete the existing data.

\section{Results and Findings}

In developing the concept and theory of bureaucracy, Hegel, Marx, Weber and Wilson explained the concept and put their views about the bureaucracy against the political interests under the political executive in the government of the country. This can be seen in table 1 below.

Table 1:. Hegel's Concept, Marx, dan Weber

\begin{tabular}{|c|c|c|c|}
\hline Concept & Bureaucracy position in society & Bureaucracy position in government & Control of the role of bureaucracy \\
\hline $\begin{array}{l}\text { Fredrik } \\
\text { Hegel }\end{array}$ & $\begin{array}{l}\text { Bureaucracy is one power among the } \\
\text { three main forces, namely the state, } \\
\text { and the forces of the particular }\end{array}$ & $\begin{array}{l}\text { Bureaucracy as a stabilizing force as be- } \\
\text { tween the interests of the state and the inter- } \\
\text { ests of a particular community. }\end{array}$ & $\begin{array}{l}\text { - the need for hierarchical bureaucratic group, } \\
\text { - Independence from interest groups } \\
\text { - Moral strength of the bureaucrats. }\end{array}$ \\
\hline Max Weber & $\begin{array}{l}\text { Bureaucracy is a professional group } \\
\text { in the society and the state }\end{array}$ & $\begin{array}{l}\text { Bureaucracy works by professionalism in } \\
\text { serving the interests of the state and society } \\
\text { and are neutral from practical politics }\end{array}$ & $\begin{array}{l}\text { Rules and regulations that form the basis of the } \\
\text { work of the bureaucracy. }\end{array}$ \\
\hline $\begin{array}{l}\text { Woodrow } \\
\text { Wilson }\end{array}$ & $\begin{array}{l}\text { Bureaucracy is a group of technical } \\
\text { professionals. }\end{array}$ & $\begin{array}{l}\text { Public bureaucracy works to serve and } \\
\text { implement policies that have been decided } \\
\text { by the Political Officers but the bureaucracy } \\
\text { works professionally and technically. }\end{array}$ & $\begin{array}{l}\text { Bureaucracy work based regulations that have } \\
\text { been decided, and oversight of the bureaucracy } \\
\text { carried out by an independent agency, or com- } \\
\text { mission of personnel }\end{array}$ \\
\hline
\end{tabular}

In addition to its queath model arrangement of bureaucratic and political officials bureaucratic system, the fourth concept still in use today. Regarding to the context of Southeast Sulawesi in particular and Indonesia in general, when we recall the New Order period [1965-1998], it was able to be categorized into the relationship pattern between executive assendency and model of Party State Bureucracy.

It has been pointed out in Carino [10] that executive assendency placed political officials as mandate holders, while bureaucratic officials were entirely within the organs of political officials in accordance with their structure. While party state buraucracy is a model of executive assendency in which the political officials came from ruling parties were either single party such as communist countries or countries that have a single majority party and control all state institutions including bureaucracy.

In the new order era, the condition was fulfilled by the following characteristics:
1. The single majority party was Golkar and the other two parties namely the United Development Party/Partai Persatuan Pembangunan [PPP] and the Indonesian Democratic Party / Partai Demokrasi Indonesia [PDI] were controlled by the ruling government.

2. Almost civil servants were Golkar cadres or were required to become cadres and won Golkar in every election. The bureaucracy was also accommodated as the main force of Golkar through three power lines namely ABRI, Bureaucracy, and Golkar.

3. The policy towards bureaucracy was set clearly from center to regions. Local political officials had high adherence to the instructions of the central government which was also the leader of their party as well as bureaucratic officials.

4. The career of bureaucratic officials was able to be shifted to the ground of political position through the cadre in Golkar, but it was not justified to be a 
sympathizer along with other member of other parties except Golkar.

5. The political officials had to obey the Golkar party's direction or his career would be going to end including the recruitment of bureaucratic officials.

That idea was in line with the results of some previous studies [11, 12] [13] who investigated the Indonesian bureaucracy as a program-oriented bureaucracy and the winning of Golkar as the election contestant who used to won the elections in Indonesia under the President Soeharto's Command who was a member of the General-Generated Military so that his leadership style also gave color in bureaucratic leadership as militaristic.

Later on, the findigns of these studies became a reference of the next scientific studies and writings, such as [10]; [14]; along with the research findings of [15] that confirmed the paternalistic culture in bureaucratic service in Indonesia, thus indicating that Indonesia bureaucratic model was consistent with the New Order pattern.

That model was a model of bureaucratic state, military dominated bureucracy. The conditions and conclusions of the research findings were relevant with the reign period of the New Order government with Golkar party as the majority party, which controled other parties [1965-1998]. The model is visualized as Figure 1.

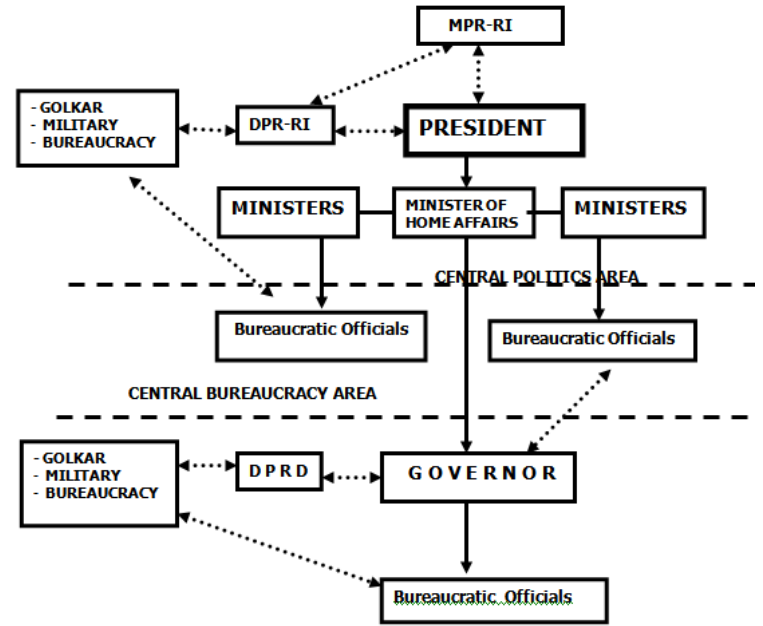

Fig. 1: Model of Executives Assendency Arrangement in New Order Era

The figure above shows the strong role of the President in the New Order era, the power of political officials is so strong even to the lowest bureaucracy. The governors, regents, and mayors are Golkar which are determined by the central Political Officials through the party's proposals in the three components of ABRI, Golkar, and Bureaucracy.

After the new order [1999 - present], the arrangement of bureaucratic and political relationship in Indonesia were not in line with the model again. Although it is still in the relationship pattern of executive assendency between political officials and bureaucratic officials, the model or variant of Party State Bureucracy is no longer can be considered as a model of Indonesian bureucracy in post-New Order [1999-Now] because of 5 . the following reasons:

1. The ruling party is not dominant,

2. The personnel management is decentralized into the regions,

3. The chief of province and regency / municipality has a majority party unlike the ruling party in central government.

4. The Bureuacratic control is not done on the party policy which become the political officials party either at center or region,

5. The policy of bureucratic carieer is on the highest politic officials' hand and undivided to the vice governor, vice regent and vice mayor.

6. The rules enforcement of the central goverment is very weak.
The model of relationship between the political officials and bureaucratic officials is visualised as Figure 2.

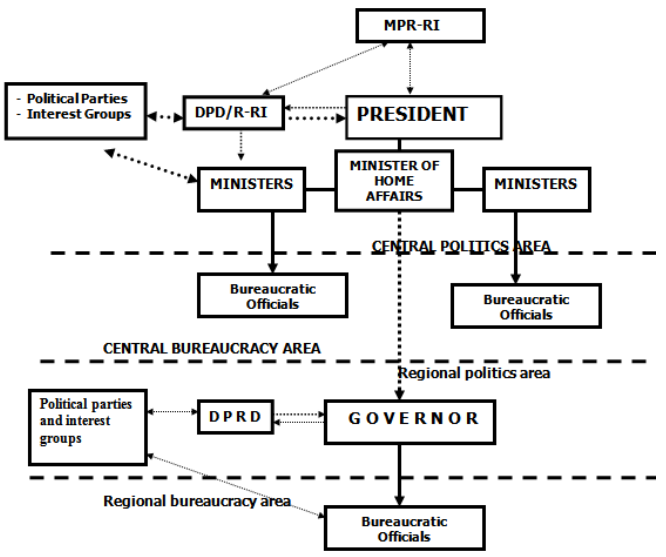

Fig. 2: Model of Executive Assendency Arrangement in Post-New Order

The model of this relationship is also not appropriate when it is purely included into the model of executive asendency. Considering, in the executive assendency, the political executive is a unity of some people or at least there is an intervention from the ruling party in parliament into the bureaucratic management policy.

In line with the character of a unity state embraced by Indonesia, it causes the parliament in region [DPRD] to be a part of the local executive even though it is elected by a general election. However, its legislative rights are derived from the constitutions. Moreover, the power of DPRD is not able to compensate the power of Governor, Regent, and Mayor in making policy especially in bureaucratic management. Therefore, it is more appropriate if the current model of bureaucratic management of governance in Indonesia, especially regional governance in Southeast Sulawesi, is called the External Model of Executive Assendency or Personal Excecutive Assendency. This is due to the policy of bureaucratic management lies on one political executive namely Governor, Regent, and Mayor who is the highest chief of the governance in provinces, districts, and municipalities.

\section{Conclusion}

From the findings and the discussion above, the writer draw the following conclusion:

1. Employment set by regulations is issued by the central government.

2. Monitoring the implementation of regulations by the central government is very weak.

3. Employment management policy in the region is submitted to the highest political official namely governor for province and regent / mayor for regency and city.

4. In taking employment policy, governor and regent/mayor are assisted by Position and Rank Consideration Board.

5. Position and Rank Consideration Board are directly appointed by the governor and regent/mayor.

6. Governor, regent / mayor, who appoints the employee based on the formation determined by the central government signs the promotion after being approved by National Civil Service Agency.

7. In holding a placement in the position, the central government provides guidance but it depends on the governor, mayor, and regent whether they want to use it completely or not.

8. Promotion is regularly carried out so that there are many similar ranks among civil servants that encourage unfair competition among civil servants.

9. Administrative violations of regulations concerning the appointment of civil servants in the office are very rarely disallowed by the central government even if the civil servants win in the court. 
If put the above conclusion in simple and brief words, it would be as follow:

1. Executive power dominates the bureaucracy.

2. Bureaucracy serves as the executor of decisions that have been decided by political officials.

3. The bureaucratic career is determined by the political executive officials.

In short, this research suggested a more appropriate model of bureaucratic management, especially regional governance in Southeast Sulawesi namely the External Model of Executive Assendency or Personal Excecutive Assendency.

\section{References}

[1] Thoha M. Birokrasi dan Politik di Indonesia, PT. Raya Grafindo Persada, Jakarta. 2003.

[2] Sutherland H, Sunarto. Terbentuknya sebuah elite birokrasi: Sinar Harapan; 1983.

[3] Masoed M. Politik, birokrasi dan pembangunan: Pustaka Pelajar; 1994.

[4] Rasyid MR. Kajian Awal Birokrasi Pemerintahan dan Politik Orde Baru. Jakarta: Yarsif Watampone. 1997.

[5] BARIROH L, Pratikno M. Politik dalam birokrasi:: Studi tentang Politisasi Birokrasi dan Politik Birokrat di Surabaya: Universitas Gadjah Mada; 2004.

[6] YUWONO T, Purwoko B. Rekrutmen untuk mengisi jabatan struktural dan beberapa faktor yang mempengaruhinya:: Studi kasus rekrutmen pejabat di Pemerintah Kabupaten Nganjuk: [Yogyakarta]: Universitas Gadjah Mada; 2003.

[7] Astuti SW. The need to strengthen bureaucracy in the use of discretionary space appropriately and accountably: Case in several Indonesian's local government. 2009.

[8] Olorunsola VA. THE RELATIONSHIP BETWEEN THE BUREAUCRATIC AND POLITICAL LEADERSHIP IN THENIGERIAN POLITY. 1968.

[9] Headey BW. THE ROLE SKILLS OF CABINET MINISTERS: A CROSS-NATIONAL REVIEW. Political Studies. 1974;22[1]:6685.

[10] Thoha AM. Tren pluralisme agama: tinjauan kritis: Gema Insani; 2005.

[11] Liddle RW. Indonesia's democratic past and future. Comparative Politics. 1992:443-62.

[12] King G. How not to lie with statistics: Avoiding common mistakes in quantitative political science. American Journal of Political Science. 1986:666-87.

[13] Crouch H. Democratic prospects in Indonesia. Asian Journal of Political Science. 1993;1[2]:77-92.

[14] Utomo W. Administrasi Publik Baru Indonesia. Perubahan Paradigma dari Ad-ministrasi Negara ke Administrasi Publik. 2006.

[15] Dwiyanto A. dkk. 2002. Reformasi Birokrasi Publik di Indonesia. 